\title{
EDITORIAL
}

\section{IMPLANTAÇÃO DO CURSO DE DOUTORADO EM ENFERMAGEM}

O Programa de Pós-graduação de Enfermagem da Universidade Federal do Paraná iniciou com a recomendação, pela Coordenação de Aperfeiçoamento de Pessoal de Nível Superior (CAPES), do curso de Mestrado Acadêmico em Enfermagem em 2003 - com o Parecer CNE/CES 0083/2003 em 9 de abril de 2003. Durante os sete anos de funcionamento do curso, em seis turmas, foram titulados 76 alunos, numa média de 13 alunos por turma, com tempo de titulação considerado como de excelência pela CAPES. No ano de 2009 foi encaminhado à CAPES a proposta do Curso de Doutorado, que recebeu a recomendação para o seu funcionamento na 114 a Reunião do Grupo de Trabalho, ocorrida nos dias 23 a 24 de novembro de 2009.

A missão do Doutorado é a qualificação de enfermeiros e demais profissionais de saúde para a produção de pesquisa, tecnologia e inovação com vistas à promoção da saúde e a proteção da vida.

Os futuros doutores deverão ser capazes de produzir conhecimento científico que contribua na prática profissional e nas diferentes dimensões da realidade; promover formação de redes de investigação científica e interdisciplinar para a produção e socialização do conhecimento que atendam as demandas da prática profissional; e desenvolver a formação de profissionais na perspectiva crítica e reflexiva, para promover e proteger a vida, qualificando a prática profissional.

A abertura do curso de Doutorado em Enfermagem fortalece o programa do Mestrado; auxilia na formação dos graduandos de enfermagem do Estado do Paraná; incrementa atividades de pesquisa e forma pesquisadores com capacidade de criação e inovação, aptos para a execução e desenvolvimento de novas propostas de ensino de pós-graduação e centros de pesquisa.

Assim, a implementação do Doutorado proporcionará acelerada capacitação de docentes, enfermeiros e demais profissionais da área da saúde, desencadeando progresso e atração de recursos para a pesquisa, desenvolvimento e inovação tecnológica nas áreas propostas e afins, bem como, regionalmente, qualificará cada vez mais a Universidade Federal do Paraná como um dos Centros de Referência Científica na Enfermagem.

$\operatorname{Prof}^{a} \operatorname{Dr}^{a}$ Maria Ribeiro Lacerda

Coordenadora do Programa de Pós-Graduação de Enfermagem da UFPR. 


\section{EDITORIAL}

\section{THE IMPLANTATION OF THE PHD IN NURSING PROGRAM}

The Graduate Nursing Program started its activities in April $9^{\text {th }}$ 2003, with the recommendation for the Academic Master in Nursing, by the Coordination of Improvement of Higher Education Personnel (CAPES) through the document CNE/CES 0083/2003. During its seven years of activities, within 6 classes, 76 students received their diplomas, with an average of 13 students per class, and CAPES considered the length for the graduation as of excellence. In 2009, we've sent the PhD Program proposal, which received recommendation for its activities in the $114^{\text {th }}$ Meeting of the Working Group of November 23 to 24, 2009.

The PhD Program mission is to qualify nurses and other health professionals to research, technology and innovation production towards health promotion and life protection.

Future $\mathrm{PhD}$ professionals must be able to produce scientific knowledge which might contribute to the professional practice and to the different dimensions of reality; to promote the conformation of interdisciplinary and scientific investigation networks to the production and socialization of knowledge accordingly to the professional practice demands; and to foster the qualification of professional by a critical and reflexive perspective to promote and protect life, qualifying the professional practice.

The beginning of a PhD in Nursing Program strengthens the Masters Program, it contributes to the Parana state undergraduate nursing students' qualification fosters research activities and coach researchers to be able both to be creative and innovative, and to the execution and development of new proposals for the graduate teaching and research centers.

Therefore, the implementation of the $\mathrm{PhD}$ will provide an accelerated training of teachers, nurses and other health professionals, triggering progress and attracting resources for research, development and technological innovation in the proposed areas, as well as regionally qualify the Federal University of Parana as one of the Reference Centers Science in Nursing.

Prof $^{a}$ Dr $^{\mathrm{a}}$ Maria Ribeiro Lacerda

Coordenadora do Programa de Pós-Graduação de Enfermagem da UFPR.

Cogitare Enferm. 2010 Jul/Set; 15(3):403-5 


\section{EDITORIAL}

\section{IMPLANTACIÓN DEL CURSO DE DOCTORADO EN ENFERMERÍA}

El Programa de Posgrado de Enfermería ha iniciado por recomendación de la CAPES, Coordinación de Perfeccionamiento de Personas de Nivel Superior del curso de Mestrado Académico en Enfermería en 2003 - con el Parecer CNE/CES 0083/2003 en 9 de abril de 2003. Durante los siete años de funcionamiento del curso, en seis clases, fueron titulados 76 alumnos, en una media de 13 alumnos por clase, con tiempo de titulación considerado de excelencia por la CAPES. En año de 2009, fue encaminada a CAPES la propuesta del Curso de Doctorado, que tuvo la recomendación para su funcionamiento en la 114a Reunión del Grupo de Trabajo, la cual ocurrió en los días 23 a 24 de noviembre de 2009.

La misión del Doctorado es la cualificación de enfermeros y otros profesionales de salud para la producción de investigación, tecnología y innovación a fin de promover la salud y la proteción de la vida.

Los futuros doctores deberán ser capaces de producir conocimiento científico que contribuya en la práctica profesional y en las diferentes dimensiones de la realidad; promover formación de redes de investigación científica y interdisciplinar para la producción y socialización del conocimiento que atendan a las demandas de la práctica profesional; y desarrollar la formación de profesionales en la perspectiva crítica y reflexiva para promover y proteger la vida, calificando la práctica profesional.

La apertura del curso de Doctorado en Enfermería fortalece el programa de Mestrado, ayuda en la formación de los graduandos de Enfermería del estado, incrementa actividades de investigación y forma investigadores con capacidad de creación y innovación, aptos para la ejecución y el desarrollo de nuevas propuestas de enseñanza de posgrado y centros de investigación.

Así, la implementación del Doctorado posibilitará una rápida capacitación de docentes, enfermeros y otros profesionales del área de la salud, traendo progreso y recursos para investigación, desarrollo y innovación tecnológica en las áreas propuestas y afines, así como, regionalmente, calificará cada vez más la Universidad Federal de Paraná como uno de los Centros de Referencia Científica en la Enfermería.

Prof $^{a}$ Dr $^{\mathrm{a}}$ Maria Ribeiro Lacerda

Coordenadora do Programa de Pós-Graduação de Enfermagem da UFPR. 